Ind. Health, 1973, 11, 38.

\title{
INCREASE OF SULFHYDRYL GROUP IN PROTEINS EXTRACTED FROM KIDNEY OF MICE ADMINISTRATED WITH CADMIUM
}

\author{
Tetsu ONO, Osamu WADA, Masaru NAGAHASHI, \\ Nobuhisa YAMAGUCHI and Kohei TOYOKAWA \\ Department of Hygiene and Preventive Medicine, Faculty of Medicine, \\ University of Tokyo, Hongo, Bunkyo-ku, Tokyo
}

(Received February 22, 1973)

The effect of administration of cadmium was investigated on the changes of the contents of sulfhydryl (SH) group and of protein in various tissues of mice after development of a simple method for the determination of SH group.

A slight increase of SH group per unit weight of kidney was observed in the supernatant of homogenate which was obtained from mice exposed to cadmium as compared with the level of control.

The increased value in the content of SH group was magnified when the proteins of kidneys of both mice groups were fractionated by alcohol-chloroform and zinc fractionation method.

When the mice were bred for seven months with a drinking water containing 0.8 mM cadmium acetate, about 7 fold increase in the content of SH group and 4 fold increase in the specific SH group value were observed in this final fraction.

It was concluded that the determination of SH group, especially by the simple method, would be a reliable biochemical parameter for cadmium exposure.

Among the reliable parameters which indicate the exposure to heavy metals, the determination of heavy metal concentrations in tissues or excreations has been widely recognized as one of the most reliable methods. The above method, however, has some advantages and disadvantages. The former consists in its higher reliability in specificity, sensitivity or accuracy, but the latter is concerned with the afraid that the result is mainly evaluated from the chemical site. The most important point of view concerning the heavy metal poisonings would be the decision of the grade of biological disturbances and also of adaptive responces caused by heavy metals. Such a biological disturvance, we believe, must be indicated by the biological or biochemical parameters in the living body. Biochemical parameters for lead exposure has been established by Wada et al. ${ }^{1,2)}$

In this paper, we intended to develop a new parameter which indicates the biological disturbance by determining the level of sulfhydryl ( $\mathrm{SH}$ ) groups in proteins, because it is widely known that the $\mathrm{SH}$ group in protein interact with 


\section{SULFHYDRYL GROUP AND CADMIUM EXPOSURE}

heavy metals. As described below we could find a protein fraction which has a wide range difference in the content of SH group between the control and cadmium exposed mice.

\section{Materials AND Method}

\section{General techniques}

Male mice of $\mathrm{F} 1$ from $\mathrm{DDD} \times \mathrm{BALB}$ strain weighing $20 \pm 2 \mathrm{~g}$ were devided into two groups. One of them was given an aqueous solution containing $0.8 \mathrm{mM}$ (about $90 \mathrm{ppm}$ as cadmium metal) cadmium acetate as a drinking water. To another control group, a tap water was given. Mice were bred in the usual way except the above drinking water. After five months' breeding, the determination of $\mathrm{SH}$ groups in proteins was started. Determinations of $\mathrm{SH}$ groups in proteins were carried out according to a slightly modified method of Sakai. ${ }^{3)}$ Data were expressed as an average value of double or triple experiments.

\section{Alcohol-chloroform fractionation}

0.5-1.0 $\mathrm{g}$ of fresh tissues from mice were homogenized with 10 fold volumes $(\mathrm{W} / \mathrm{V}$ or $\mathrm{V} / \mathrm{V})$ of a mixed solution containing $0.9 \%$ saline, ethanol and chloroform $(90: 126: 9.2, \mathrm{~V} / \mathrm{V})$. The homogenates were collected in tubes, followed by the standing for overnight at $4^{\circ} \mathrm{C}$. Supernatant was collected by centrifugation at $600 \mathrm{G}$ for $10 \mathrm{~min}$.

\section{Zinc fractionation}

To the supernatant of alcohol-chloroform fraction, an equal volume of acetone was added. After $1 \mathrm{hr}$, precipitate was collected by centrifugation at $600 \mathrm{G}$ for $5 \mathrm{~min}$. The precipitate was resolved in $1.5 \mathrm{ml}$ of distilled water, followed by the addition of $1.5 \mathrm{ml}$ of solution containing $20 \mathrm{mM}$ of each zinc acetate and sodium acetate. After $20 \mathrm{~min}$ of standing, supernatant and precipitate were devided by centrifugation at $600 \mathrm{G}$ for $5 \mathrm{~min}$.

\section{RESUlts}

Five months' breeding of mice did not show a notable difference between the two groups in regard to the weights of body, liver and kidney.

First of all, the content of SH group in the supernatant of homogenate was compared between two mice groups. As shown in Table 1, the average content of SH group in liver was high in comparison with that of kidney, but the difference in the content of $\mathrm{SH}$ group between the two mice groups was distinct in the latter.

When the kidneys were fractionated by alcohol-chloroform method, the difference in the content of $\mathrm{SH}$ group was magnified between two groups (Table 2). Furthermore, a clearer magnification of the difference was observed in the content of SH group when the kidneys of both mice groups were fractionated by alcoholchloroform and zinc fractionation method. In this final fraction, 4.3 fold moles of 


\section{T. ONO, O. WADA, M. NAGAHASHI, N. YAMAGUCHI AND K. TOYOKAWA}

Table 1. Effects of cadmium administration on the contents of SH group and of protein in the supernatant of homogenates extracted from livers and kidneys.

\begin{tabular}{llcccccc}
\hline \multirow{2}{*}{ Tissues } & Mice group & SH $(\mu \mathrm{mole})$ & $\%^{\dagger}$ & Protein $(\mu \mathrm{g})$ & $\%^{\dagger}$ & $\frac{\mu \text { mole SH }}{\text { mg protein }}$ & $\%^{\dagger}$ \\
\hline \multirow{2}{*}{ Liver } & Control & 0.059 & 100 & 703 & 100 & 0.084 & 100 \\
& Cd exposed & 0.067 & 114 & 739 & 105 & 0.091 & 108 \\
\hline \multirow{2}{*}{ Kidney } & Control & 0.035 & 100 & 563 & 100 & 0.062 & 100 \\
& Cd exposed & 0.049 & 140 & 590 & 105 & 0.083 & 136 \\
\hline
\end{tabular}

Mice were bred for 7 months as described in the text. 10\% homogenates of livers and kidneys from mice groups were prepared with $0.9 \%$ saline. Supernatants of the homogenates were collected by centrifugation at $600 \mathrm{G}$ for $10 \mathrm{~min}$. Determinations of SH group and of protein were carried out using the $0.1 \mathrm{ml}$ aliquots of each supernatant from the homogenates.

$\dagger$ Values indicate the increase as percentage of the control.

Table 2. Effects of alcohol-chloroform fractionation on the contents of $\mathrm{SH}$ group and of protein in kidn€ys.

\begin{tabular}{lcccccc}
\hline Mice group & SH $(\mu$ mole $)$ & $\%^{\dagger}$ & Protein $(\mu \mathrm{g})$ & $\%^{\dagger}$ & $\frac{\mu \text { mole SH }}{\text { mg protein }}$ & $\%^{\dagger}$ \\
\hline Control & 0.024 & 100 & 409 & 100 & 0.059 & 100 \\
Cd exposed & 0.071 & 296 & 654 & 160 & 0.109 & 185 \\
\hline
\end{tabular}

Mice were bred for 5 months as described in the text. $0.5 \mathrm{~g}$ of kidneys from both mice groups were fractionated by the method of alchol-chloroform fractionation.

$\dagger$ Values indicate the increase as percentage of control.

Table 3. Effects of alcohol-chloroform and zinc fractionation on the contents of $\mathrm{SH}$ group and of protein.

\begin{tabular}{llcccccc}
\hline $\begin{array}{c}\text { Zinc frac- } \\
\text { tionation }\end{array}$ & Mice group & SH $(\mu$ mole $)$ & $\%^{\dagger}$ & Protein $(\mu \mathrm{g})$ & $\%^{\dagger}$ & $\frac{\mu \text { mole SH }}{\text { mg protein }}$ & $\%^{\dagger}$ \\
\hline \multirow{2}{*}{ Supernatant } & Control & 0.010 & 100 & 162 & 100 & 0.062 & 100 \\
& Cd exposed & 0.043 & 430 & 363 & 224 & 0.118 & 190 \\
\hline \multirow{2}{*}{ Precipitate } & Control & 0.014 & 100 & 257 & 100 & 0.055 & 100 \\
& Cd exposed & 0.028 & 200 & 292 & 114 & 0.096 & 175 \\
\hline
\end{tabular}

Mice were bred for 5 months as described in the text. $0.5 \mathrm{~g}$ of kidneys from both mice groups were fractionated.

$\dagger$ Values indicate the increase as percentage of the control.

SH group per unit weight of kidney were observed in the cadmium-treated group as compared with the level in the control and about 1.9 fold in the specific SH group as shown in Table 3. 


\section{SULFHYDRYL GROUP AND CADMIUM EXPOSURE}

Table 4. Effects of alcohol-chloroform and zinc fractionation on the contents of $\mathrm{SH}$ group and of protein in various tissues.

\begin{tabular}{|c|c|c|c|c|c|c|c|c|}
\hline Tissues & $\begin{array}{l}\text { Weight or } \\
\text { volume }\end{array}$ & Mice group & $\underset{(\mu \mathrm{mole})}{\mathrm{SH}}$ & $\%+$ & $\begin{array}{l}\text { Protein } \\
\quad(\mu \mathrm{g})\end{array}$ & $\%^{\dagger}$ & $\frac{\mu \text { mole SH }}{\mathrm{mg} \text { protein }}$ & $\%^{\dagger}$ \\
\hline \multirow{2}{*}{ Kidney } & \multirow{2}{*}{$0.6 \mathrm{~g}$} & Control & 0.012 & 100 & 219 & 100 & 0.055 & 100 \\
\hline & & Cd exposed & 0.085 & 708 & 374 & 170 & 0.227 & 414 \\
\hline \multirow{2}{*}{ Liver } & \multirow{2}{*}{$1.0 \mathrm{~g}$} & Control & 0.043 & 100 & 828 & 100 & 0.052 & 100 \\
\hline & & Cd exposed & 0.097 & 226 & 1125 & 136 & 0.086 & 165 \\
\hline \multirow{2}{*}{ Blood cells } & \multirow{2}{*}{$1.3 \mathrm{ml}$} & Control & 0.012 & 100 & 320 & 100 & 0.038 & 100 \\
\hline & & Cd exposed & 0.013 & 108 & 335 & 104 & 0.039 & 102 \\
\hline \multirow{2}{*}{ Plasma } & \multirow{2}{*}{$0.7 \mathrm{ml}$} & Control & 0.004 & 100 & 46 & 100 & 0.087 & 100 \\
\hline & & Cd exposed & 0.004 & 100 & 42 & 91 & 0.095 & 109 \\
\hline
\end{tabular}

Mice were bred for 7 months. Tissues were fractionated as described in the text. Bood cells were obtained by the centrifugation of heparinized blood at $750 \mathrm{G}$ for $20 \mathrm{~min}$.

$\dagger$ Values indicate the increase as percentage of the control.

To compare the tissue difference in the content of this final fraction, kidneys, livers, blood cells and plasma of both mice groups were fractionated and the $\mathrm{SH}$ group contents were determined (Table 4). The most distinct difference between the two mice groups was observed in the kidney. When mice were bred for 7 months with a drinking water containing cadmium, about 7 fold increase in the content of SH group and 4 fold increase in the specific SH group value were obtained.

During these experiment, no notable change in the content of $\mathrm{SH}$ group per unit weight was observed in kidneys of control mice.

\section{Discussions}

In this research, an obvious increase of $\mathrm{SH}$ group was shown in a part of kidney proteins of mice exposed to cadmium.

Of the two fractionation methods, alcohol-chloroform fractionation is partly similar to that for metallothionein purification. ${ }^{4}$ Moreover, it is also well known that metallothionein which has many $\mathrm{SH}$ groups in its molecule ${ }^{4,5)}$ is increased in some tissues of cadmium-exposed animals. ${ }^{6}$ ) The fraction in which $\mathrm{SH}$ group was increased by the exposure to cadmium, therefore, might be the metallothionein rich fraction. As shown in Table 1, the average content of $\mathrm{SH}$ group in the protein extracted from kidneys of control mice had a mole of SH group per 16,000 $\mathrm{g}$ of protein. On the other hand, the content of $\mathrm{SH}$ group in the fraction of kidneys from mice which were exposed to cadmium (Table 4) was caluculated as a mole SH group per $4,400 \mathrm{~g}$ of protein. If this fraction is the metallothionein rich fraction and if the rest proteins have a mole $\mathrm{SH}$ group per $16,000 \mathrm{~g}, 6.5 \%$ of the protein in this fraction obtained from kidneys of cadmium treated mice would 
T. ONO, O. WADA, M. NAGAHASHI, N. YAMAGUCHI AND K. TOYOKAWA

be metallothionein and about $74 \%$ of $\mathrm{SH}$ group in this fraction would originate from metallothionein on the basis of caluculation that the content of $\mathrm{SH}$ group in metallothionein has been reported as a mole per $385 \mathrm{~g} .^{.5}$

Considering the ratio of the content of SH group in the final fraction from cadmium-treated mice to that from the control per unit weight of fresh kidney, the content of SH group was increased steadily during the experiment (Table 3 and 4). This fact might suggest the existence of a dose response relationship between the grade of cadmium exposure and the content of SH group in this fraction.

These results indicate that the determination of $\mathrm{SH}$ group by the simple method developed in this report would be a reliable biochemical parameter for cadmium exposure.

\section{ACKNOWLEDGEMENT}

The authors are grateful to Drs. Yano, Y., Kurashina, S., Yazaki, K. and Ono, $\mathrm{H}$. in their laboratory for the encouraging discussions and advices.

\section{REFERENCES}

1) Wada, O., Ono, T., Maru, R. and Toyokawa, K. (1972). Ind. Health, 10, 11.

2) Nakao, K., Wada, O. and Yano, Y. (1968). Clin. Chim. Acta, 19, 319.

3) Sakai, H. (1968). Anal. Biochem., 26, 269.

4) Kägi, J.H. R. and Vallee, B. L. (1960). J. Biol. Chem., 235, 3460.

5) Pulido, P., Kägi, J.H. R. and Vallee, B.L. (1966). Biochemistry, 5, 1768.

6) Shaikh, Z.A. and Lucis, O. J. (1970). Federation. Proc. 29, 301 Abs.. 